\title{
ADJUSTMENT TO COLLEGE WORK AND ITS RELATIONSHIP WITH PSYCHOLOGICAL DISTRESS IN INTERNATIONAL STUDENTS AT THE UNIVERSITY OF INDONESIA
}

\author{
Bianca Marella $^{1}$, Wuri Prasetyawati ${ }^{2}$ \\ ${ }^{1}$ Faculty of Psychology, Tarumanegara University, \\ Jl. Letjen S.Parman no.1. Jakarta 11440, Indonesia \\ ${ }^{2}$ Faculty of Psychology, University of Indonesia, \\ Jl. Lkr Kampus Raya Blok Mawar no.5. Depok 16424, Indonesia \\ biancam@fpsi.untar.ac.id
}

\begin{abstract}
Relocation can be a challenging and stressful experience for most international students. The demands of cultural adjustments frequently place international students at greater risk for various psychological problems than students in general. This research aims to describe the relationship between adjustment to college work problems and psychological distress. A cross-sectional survey with a self-completion questionnaire was conducted in a convenience sample of international students in Universitas Indonesia. Using convenience sampling, 107 international students $(51.4 \%$ male, mean age $=25.7$ years, $S D=5.65)$ completed the Hopkins Symptoms Checklist-25 (HSCL-25), a measurement of psychological distress, and the Mooney Problem Checklist Adjustment to College Work scale as a measurement of adjustment to college work. Using the HSCL-25 score 1.75 as a cut-off, 28 participants $(26.2 \%)$ reports a high psychological distress level. Pearson correlation demonstrates that there is no significant correlation between adjustment to college work problems and psychological distress. Further analysis for each adjustment-problem item was carried out to explore specific academic problems faced by international students. We found that the problems "Worrying about examination" $(r=.194, p<.05)$ and "Fearing in failure in college" $(r=.218 p<.05)$ were significantly associated with psychological distress. It is advisable for education institutions that accept international students to provide academic counselors or train local students to help international students.
\end{abstract}

Keywords: adjustment to college work; psychological distress; international students; Universitas Indonesia; HSCL-25

\begin{abstract}
Abstrak
Mahasiswa asing berpotensi mengalami distres psikologis yang dapat ditimbulkan oleh relokasi tempat tinggal, perbedaan budaya, serta penyesuaian terhadap sistem pendidikan yang baru. Penelitian ini bertujuan untuk melihat apakah masalah adjustment to college work memiliki hubungan signifikan dengan distres psikologis pada mahasiswa asing di Universitas Indonesia. Menggunakan convenience sampling, 107 mahasiswa asing (51,4\% laki-laki, rata-rata usia 25,7 tahun, $S D=5,65)$ dari program degree dan non-degree direkrut untuk melengkapi alat ukur HSCL-25 (25 aitem; $\alpha=0,93$ ) untuk mengetahui tingkat distres psikologis, dan instrumen Mooney Problem-Checklist (30 aitem) untuk mendata masalah adjustment to college work. Dengan menggunakan skor 1,75 sebagai penentu, 28 mahasiswa asing (26,2\%) diketahui memiliki level psychological distress yang tinggi. Analisis data dengan korelasi Pearson menunjukkan bahwa tidak ada hubungan antara masalah adjustment to college work dengan distres psikologis. Analisis lanjutan per aitem permasalahan dilakukan untuk mengetahui secara spesifik permasalahan akademik yang dihadapi mahasiswa asing. Diketahui bahwa masalah "Mencemaskan ujian-ujian" ( $r=0,194, p<0,05)$ dan "Takut gagal di perguruan tinggi" $(r=0,218, p<0,05)$ memiliki hubungan signifikan dengan distress psikologis pada mahasiswa asing di UI. Institusi pendidikan yang menerima mahasiswa asing dapat menyediakan konselor atau memberdayakan mahasiswa lokal untuk membantu proses penyesuaian akademik mahasiswa asing.
\end{abstract}

Kata kunci: adjustment to college work, psychological distress, mahasiswa asing, Universitas Indonesia, HSCL25 


\section{INTRODUCTION}

On a national scale, the University of Indonesia (UI) has been recognized as one of Indonesia's best universities and awarded the first-class accreditation by BAN-PT following 5239 / SK / BAN-PT / Akred / PT / XII / 2017. On an international scale, UI's rank is the highest among other leading Indonesian universities in the 2018 QS Asian University Rankings (QS Asian University Rankings, 2018). UI becomes a World Class University by improving the quality of higher education institutions with international standards as a contribution to the country. One of the efforts to increase international capacity is by providing international study programs. Since 2015, there have been 7.892 international students taking various academic programs at UI (Ayu, 2019). This number is relatively small compared to one of the public universities in Malaysia with 21.055 international students from 80 different countries recorded in 2019. UI always tries to attract international students to study at UI (Ayu, 2019). Study programs for international students are divided into two, degree and nondegree programs. Degree programs are the International Special Class program (KKI) and student exchange programs, while nondegree program is the Indonesian Language for Foreign Speakers (BIPA) program. At the end of the study, international students from each program must write scientific papers as final credit of their learning outcomes. These two international student programs are also in collaboration with other universities. For example, in the BIPA program, based on an interview with the BIPA program manager, Puspitorini (2013), most students who attend BIPA are international students from abroad, who want to improve Indonesian language proficiency. The BIPA program itself was created to prepare international students who want to continue their studies at UI or, in a broader scope, at other universities in Indonesia. International students who intend to continue their studies at the University of Indonesia are required to undertake an education program at BIPA (UI, 2020). Some international students continue to a degree program at UI after completing their studies at the BIPA program (Puspitorini, 2013). BIPA also provides a credit transfer system for international students who want to return to their universities at origin country after completing their studies at BIPA.

Education is no longer confined to the national domain. The increasing international students' mobility promotes policy formulation for the national higher education framework. The adjustment process in international students has thus received a lot of attention from researchers in various countries (Smith \& Khawaja, 2011; Zhang \& Goodson, 2011; Wang et. al, 2012; Mesidor \& Sly, 2016). With the increasing number of international students, an understanding of the psychological factors that facilitate adaptation is becoming ever more important. The obstacles and challenges faced by international students are more massive than those faced by local students (Mori, 2000; Sherry, Thomas, \& Chui, 2010). The challenges experienced by international students include difficulties in adapting to the new academic system (Sherry, Thomas, \& Chui, 2010; Shu, Ahmed, Pickett, Ayman, \& McAbee, 2020), local culture (Sherry, Thomas, \& Chui, 2010), the new living environment (Smith \& Khawaja, 2011), and the reducing social support (Sherry, Thomas, \& Chui, 2010).

Stress occurs when an individual is confronting by urgent and unexpected situations or circumstances that come from outside the individual. Negative feelings, such as loneliness, homesickness, culture shock, and isolation, can cause a great sense of helplessness in international students that manifested in the form of depression and anxiety (Mori, 2000). Previous research noted psychological distress as one of the manifestations of stress symptoms, are often encountered in international students (Zhang \& Goodson, 2011; Hwang, Bennett \& Beauchemin, 2014). Adjustment, a psychological process in which individuals can regulate or overcome various pressures or 
demands, is needed to meet environmental and social demands as a form of problemsolving (Israelashvili, M., 2012; Anderson, Guan \& Koc, 2016). Stress experienced during the adjustment process interferes with the problem-solving process by inhibiting cognition and causing defensive mechanisms (Israelashvili, M., 2012), so that individuals with stress will find it difficult to solve the problems in the adjustment process. Based on the explanation above, adjustment and stress can influence each other. The adjustment process can cause distress, and vice versa.Academic problems can cause stress for students (Yusoff, Rahim, \& Yaacob, 2010; Waghachavare, Dhumale, Kadam, \& Gore, 2013). In general, international students studying in other countries have gone through various selections that predict their education success (Bastien, 2011). Expectations and hopes for success often encourage international students to focus on academic achievement and adjust self to the academic system (Mori, 2000; Bastien, G. et al. 2018). Mooney \& Gordon (Heppner, P. P., Kivlighan, D. M., Good, G. E., Roehlke, H. J., \& et al., 1994) listed problems commonly encountered during the adjustment process in the college world, for example, individuals' problems in facing the demands of assignments in a curriculum, individual learning abilities. These are the concept of an adjustment problem to college work.

Previous studies examined the various context of international students. The results of Shaifa \& Supriyadi's (2013) study of international students in Bali reported that as many as $40 \%$ of the total participants had low and deficient levels of adjustment. Meanwhile, other research focusing on cultural adjustment and coping strategies in international students in Samarinda City found that international students experience stressors from the environment such as cultural differences, climate, cleanliness and community habits. These stressor cause discomfort in international students (Salmah, 2016). So far, there is still limited research about international students in Indonesia that focuses on adjustments in the academic field, despite the ever-growing concern on the mental health of international students. Based on the description above, this study aims to examine the relationship between adjustment to college work and psychological distress in international students and to obtain a description of psychological distress and academic adjustment problems experienced by international students at the University of Indonesia. The hypothesis proposed in this study is: there is a relationship between adjustment to college work and psychological distress in international students at the University of Indonesia.

\section{METHODS}

\section{Research Participants}

Participants in this study were 107 international students from non-degree programs (BIPA) and degree programs (KKI) in 2013, with the following criteria: (1) students with nationalities other than Indonesia, (2) participating in academic activities at the University of Indonesia, (3) having the status legal student visa, (4) has lived in Indonesia for at least two months, and (5) currently registered as an active student. International students in degree programs can be undergraduate or postgraduate students. The sample was obtained through a convenience sampling technique.

\section{Adaptation of Research Instruments}

The participants filled out the questionnaire, and the data were collected. The process of adapting the questionnaire from English to Indonesian, Korean and Japanese refers to the translation stages of Brislin (1970), which consists of direct translation, back translation, and decentering stages. The first stage, the English questionnaire was translated into the other three languages by the first linguist. The second stage, the translated questionnaire was matched with meaning and was translated back into English by a second language expert. The third stage, the translated 
questionnaire was distributed to five international students for legibility checking. Each linguist is a bilingual, fluent in Indonesian and other foreign languages, as required in this study. The international students who checked the legibility were not included as research participants.

\section{Research Instruments}

\section{a. Psychological distress.}

The HSCL-25 is a self-report instrument consisting of 25 items to measure the appearance and intensity of depression and anxiety symptoms. Items that measure symptoms of anxiety include items about sudden unexplained fear, feelings of easy fear, fainting, dizziness or weakness, nervousness and palpitations, and feelings of tension or stiffness. Meanwhile, items that measure depressive symptoms include items about feeling less energy or slow in acting, blaming yourself for something, easy crying, no sexual interest or pleasure, and decreased appetite. Hopkins Symptoms Check List-25 (HSCL25 ) is an instrument that is widely used to identify symptoms of anxiety and depression (Kaaya, Fawzi, Mbwambo, Lee, Msamanga, Fawzi, 2002; Turnip, Klungsøyr, O. \& Hauff, 2010; Tirto \& Turnip, 2019). Kaaya et al. (2002) also explained that HSCL-25 is an instrument that can be used across cultures. The process of adapting HSCL-25 can be found in other studies (Turnip \& Hauff, 2007).

The internal consistency of the Cronbach's HSCL-25 alpha was 0.93, for the depression and anxiety subscale. Based on these results, HSCL-25 is consistent in measuring the level of distress. Each HSCL-25 item is measured using a Likert scale, with a scale ranging from 1 to 4, from 'not at all disturbing' to 'very disturbing'. The HSCL-25 score obtains by dividing the sum of an individual score by the answered questions. The resulting score ranges from 1.00 - 4.00. HSCL has a cut-off score of 1.75 . If a participant gets a score more than who or equal to 1.75 , it means she or he has a disorder (Kaaya et al., 2002).

\section{b. Adjustments to college work.}

The instrument used to view problems related to college life is the Mooney Problem Checklist 1950 Revisions. Mooney Problem Checklist 1950 Revisions were constructed by Ross L. Mooney and Leonard V. Gordon. This instrument is for students and aims to help students to express their personal problems. Students were asked to read each item, underline the item that represents their problems, and circle the issues they focused on. This instrument has been adapted and used in many researches on problems encountered by international students at other universities (Alavi \& Mansor, 2011).

Mooney Problem Checklist 1950 Revisions has 363 items describing student problems, which are divided into 12 domains, namely: Health \& Physical Development (HPD), Finance Living Condition Employment (FLE), Social \& Recreational Activities (SRA), Social-Psychological Relations (SPR), Personal Psychological Relations (PPR), Courtship, Sex \& Marriage (CSM), Home \& Family (HF), Moral \& Religion (MR), Adjustment to college work (ACW), The Future Vocational \& Educational (FVE), Curriculum \& Teaching Procedure (CTP) and Current Issues (CI). In this study, the researcher took several Mooney items in the realm of adjustment to college work to see their relationship with psychological distress. The examples of these items include (1) not knowing how to study effectively, (2) it is easy to lose concentration while studying, (3) not having a learning plan.

\section{Data analysis}

This study used several methods to analyze the data. Descriptive analysis was used to describe the demographic distribution of the study participants, while Pearson correlation was used to empirically test the relationship between adjustment to college work and psychological distress in international students. The data were processed with the SPSS 18. 


\section{RESULTS AND DISCUSSION}

A total of 121 participants returned the questionnaire, fourteen of them could not be included in the analysis due to incomplete data. Table 1 shows the overview of research participants.

Table 1.

Characteristics of international students at UI

\begin{tabular}{cccc}
\hline Characteristics & Description & Frequency & Percentage \\
\hline \multirow{3}{*}{ Sex } & Male & 55 & $51.4 \%$ \\
& Female & 35 & $32.7 \%$ \\
& Unknown & 17 & $15.9 \%$ \\
\hline \multirow{3}{*}{ Nationality } & South Korea & 56 & $52.3 \%$ \\
& Japan & 18 & $16.8 \%$ \\
& Others & 33 & $30.8 \%$ \\
\hline \multirow{2}{*}{ Age } & 18 - 30 years old & 81 & $75.7 \%$ \\
& $\geq 31$ years old & 15 & $14 \%$ \\
& Unknown & 11 & $10.3 \%$ \\
\hline \multirow{3}{*}{ Academic Program } & Non-degree & 51 & $47.7 \%$ \\
& Degree & 41 & $38.3 \%$ \\
& Unknown & 15 & 14 \\
\hline
\end{tabular}

A total of 107 participant data were included in the analysis. Table 1 shows that the majority of the participants were male (51.4\%), came from South Korea (52.3\%), aged $18-30$ years $(75.7 \%)$, and came from non-degree study programs, namely the BIPA program $(47.7 \%)$.

Table 2.

Psychological distress on international students at UI

Psychological distress

$<1.75$

$\geq 1.75$

$\begin{array}{cc}N & \text { Percentage } \\ 79 & 73.8 \% \\ 28 & 26.2 \%\end{array}$

Meanwhile, 79 subjects have a cut-off score below 1.75 , meaning that the subjects have a low psychological distress level.
Of the 107 subjects, there were 28 subjects have a cut-off score greater than or equal to 1.75 , which means that the subjects have a high level of psychological distress.

Table 3.

Psychological distress level based on sex

\begin{tabular}{ccccc}
\hline & High Distress & $\%$ & Low Distress & $\%$ \\
\hline Male & 12 & 11.2 & 54 & 50.5 \\
Female & 16 & 15 & 25 & 23.3 \\
\hline Total & 28 & 26.2 & 79 & 73.8 \\
\hline
\end{tabular}

From the above table, we could see that female participants have higher levels of distress than males $(15 \%$ and $11.2 \%$, respectively). Meanwhile, most participants identified with low distress level (73.8\%), with male participants accounted for more than half of the proportion $(50.5 \%)$.

The correlation results of psychological distress and adjustment to college work shows a correlation coefficient $(r)$ of .111 with $p>$ .05 , which means it is not significant (two- 
tailed). These results indicate that the null hypothesis (Ho) is accepted and the alternative hypothesis (Ha) is rejected. Thus, it can be interpreted that there is no relationship between psychological distress and adjustment to college work for international students at the University of Indonesia. The researcher examined the items in the adjustment problems to college work that were significantly related to psychological distress.

Table 4.

Relationship between Adjustment to College Work items and Psychological Distress

\begin{tabular}{|c|c|c|}
\hline Adjustment to College Work & $\begin{array}{c}\text { Pearson } \\
\text { correlation }\end{array}$ & $p$ \\
\hline Not knowing how to study effectively & .051 & .600 \\
\hline Easily distracted from my work & .020 & .840 \\
\hline Not planning my work ahead & -.012 & .903 \\
\hline Having a poor background for some subjects & -.017 & .858 \\
\hline Inadequate high school training & -.058 & .550 \\
\hline Forgetting things I've learned in school & .144 & .139 \\
\hline Getting low grades & .165 & .091 \\
\hline Weak in writing & -.061 & 532 \\
\hline Weak in spelling and grammar & -.054 & .579 \\
\hline Slow in reading & -.091 & .352 \\
\hline Not spending enough time in study & .027 & .785 \\
\hline Having too many outside interests & .127 & .194 \\
\hline Trouble organizing term papers & -.035 & .717 \\
\hline Trouble in outlining or note-taking & .002 & .983 \\
\hline Trouble with oral reports & .046 & .636 \\
\hline Not getting studies done on time & .190 & .051 \\
\hline Unable to concentrate well & .106 & .278 \\
\hline Unable to express myself well in words & .148 & .127 \\
\hline Vocabulary too limited & -.020 & .840 \\
\hline Afraid to speak up in class discussions & .114 & .244 \\
\hline Worrying about examination & $.194 *$ & .046 \\
\hline Slow with theories and abstractions & -.082 & .404 \\
\hline Weak in logical reasoning & -.152 & .117 \\
\hline Not smart enough in scholastic ways & -.029 & .764 \\
\hline Fearing in failure in college & $.218 *$ & .024 \\
\hline Not having a well-planned college program & -.025 & .798 \\
\hline Not really interested in books & -.057 & .558 \\
\hline Poor memory & .070 & .473 \\
\hline Slow in mathematics & .083 & .397 \\
\hline Needing a vacation from school & .092 & .353 \\
\hline
\end{tabular}

Note. $* p<.05$ (2-tailed).

In Table 4. shows that the "Fear of failing in college" and "Worrying about exams" have a significant relationship with psychological distress in international students at the University of Indonesia. The correlation coefficient result $(r)$ for the item "Fear of failing in college" is .218 with $p<.05$, which means significant (two-tailed). Meanwhile, the correlation coefficient $(r)$ for the item "Worrying about the tests" is .194 with $p<$ .05, which means significant (two-tailed). 
The results of this study are not following the research hypothesis, which states that there is a significant negative relationship between adjustment to college work and psychological distress. Previous studies discussed the relationship between psychological distress and adjustment levels in international students with factors of the education system, language skills, social support, the influence of the local environment, and individual factors. These five factors will emerge in academic and nonacademic contexts which may explain the inconsistency of this research result with the research hypothesis.

International students often face academic difficulties, like finding and understanding the education system in the new country (Smith \& Khawaja, 2011; Khawaja \& Stallman, 2011). It is considered that factors such as building relationships with university employees and classmates, teaching styles of teachers, and differences in the curriculum can affect the academic performance of international students in new countries (Smith \& Khawaja, 2011). The majority of participants in this study come from South Korea and Japan. The education systems in these two countries share several similarities with the education system in Indonesia, in terms of the quantity of course material, learning duration in one lecture class, type of curriculum, and teaching methods. The difference is on the academic demands placed on South Korean and Japanese students. Um (2018) shows that a number of South Korean teenage students experience problems with school adjustment, and this leads to psychological problems such as anxiety, anger, depression and the tendency to self-harm. Even though there are alterations in the admission system and the examination system, students still have feelings of helplessness so that adjustment will be more difficult. The routine face-to-face study scheduled for the BIPA program starts at nine in the morning until noon. The duration of this study is much shorter than the regular study hours for high school students in South Korea and Japan.
Language skills have a strong relationship with adjustments in the academic field of international students (Sherry, Thomas, \& Chui, 2010; de Araujo, 2011; Wu, Garza, \& Guzman, 2015). Low language proficiency can reduce students' tendency to seek social interactions, which then reduces access to information that might facilitate adjustment (Sherry, Thomas, \& Chui, 2010; Smith \& Khawaja, 2011). Based on the researcher's observation, international students tend to gather with their companion (fellow citizen) in every activity, for example when doing joint assignments at the Central Library, having lunch, or when taking breaks in the middle of lessons. Previous research has found that international students feel comfortable when they are in a community of international students or students who come from the same country (Sherry, Thomas, \& Chui, 2010; Wu \& Hammond, 2011). Social interactions with individuals from similar culture backgrounds can facilitate the adjustment of international students by maintaining a relationship with their original cultural values (Sherry, Thomas, \& Chui, 2010; Shu, Ahmed, Pickett, Ayman, \& McAbee, 2020). Apart from the language of their home country, international students can also use English to communicate. The interest of the Indonesian people to learn English increases. English proficiency is still considered as one of the skills that must be mastered by Indonesian to be more competitive in the school's world, colleges, and also in the career world (Sherry, Thomas, $\&$ Chui, 2010). Participants are surrounded by educated people with good English understanding and communication It can be assumed that international students at UI do not experience significant difficulties in communicating their academic and daily needs.

Language skills also play a role in international students' mental health in nonacademic factors, such as social support. The social networks vary among individuals. It depends the meeting frequency and relationship closeness (Shu, Ahmed, Pickett, 
Ayman, \& McAbee, 2020). Individuals receive social support from not only from their family, but also from friends and partners. Thus, family are not the only main source of social support for international students. Individuals with the same cultural background are likely able to be another source of social support for international students. The International students at UI can receive social support from friends, both from the same and different nationality. International students building friendships with fellow international students or local students tend to experience an excellent adjustment process (Shu, Ahmed, Pickett, Ayman, \& McAbee, 2020) and lower levels of negative emotions (Sherry, Thomas \& Chui, 2010). The results of Wang et al. (2012) found that international students with high support levels tended to have high levels of adjustment and lower levels of depression. According to the description regarding the relationship between a low psychological distress level and a good adjustment process, it can be assumed that international students at the University of Indonesia have adequate sources of social support. Social support is one of the factors associated with the level of psychological distress for international students at the University of Indonesia, although the source and form of social support are not yet known with certainty.

Apart from social support, interaction with a similar environment can facilitate international students' adjustment process (Sherry, Thomas \& Chui, 2010; Shu, Ahmed, Pickett, Ayman, \& McAbee, 2020). Indonesia's culture is familiar to Japanese and South Korean. The number of Korean pop (Kpop) fans in Indonesia increases dramatically over the past five years. Within the campus of University of Indonesia, there are several Korean restaurants, and Japanese restaurants are also to find in the Depok area. UI also has a Student Activity Unit (UKM) facilitating fans of Korean culture and arts. Aslo, UI has Japanese Studies Center (PSJ) to facilitate cultural introduction and opportunities for cooperation with Japan. It can be concluded that the UI environment is open to the presence of international students, mostly Korean and Japanese students who are the majority of international students at UI.

College adjustment is associated with three factors, academic factors, social factors, and individual factors, such as locus of control (Aspelmeier, Love, McGill, Elliott, \& Pierce, 2012). Locus of control has a significant relationship with academic adjustment and social factors, because students with an internal locus of control have a better academic adjustment (Stoeber, J. et al., 2011; Aspelmeier et al., 2012; Sagone \& De Caroli, 2014). Researchers argue that internal locus of control is related to individual development tasks. The study participants were $20-40$ years old. Individuals in this age range have selffocused characteristics (Schwartz, Zamboanga, Luyckx, Meca, \& Ritchie, 2013), a condition where individuals feel they can make life choices without parental help and are more open to new provided things in different environments. In this tudy, International students are likely aware of the risks and difficulties they may experience in Indonesia and understand their adjustment ability. Students with an adequate level of adaptation and problem-solving abilities, actively engaged with academic activities and environment, are proven to be able to adjust well in college life (Sherry, Thomas, \& Chui, 2010; Khawaja, \& Stallman, 2011; Zhang \& Goodson, 2011).

The analysis results also showed that international students did not have academic problems related to material, study time, and effective learning strategies. However, their psychological distress was significantly associated with anxiety in facing exams and the likelihood of failing in college. This can happen when they do not understand the education system's provisions or the lecture's expectations in their study (Wu, Garza, \& Guzman, 2015).

The results of this study have several following limitations. First, the proportion of 
South Korea participants was more than participants from other countries, although their country of origin was not correlated with the dependent variable in this study, like psychological distress. This happens because international students from South Korea have the largest proportion of total international students studying at UI in the year of data collection. Second, this study is a crosssectional study so that in order to get an overview of the causal relationship between the research variables, further research may consider longitudinal research designs.

\section{CONCLUSION}

This study examines the relationship between adjustment to college work and psychological distress in international students at the University of Indonesia. The results show no relationship between adjustment to college work and psychological distress for international students at UI. They have a low level of psychological distress and do not have significant adjustment problems in college work. The additional analysis indicated that international students at the University of Indonesia had two problems that were significantly related to psychological distress, namely the problem of "Worrying about examinations" and "Fear of failing in college." Sociocultural factors are factors that are always found to be associated with the adjustment of international students. The researcher argues that if this factor is added as a supporting factor for adjusting to college for international students, a broader explanation will be obtained regarding the factors related to psychological distress in international students at UI.

\section{REFERENCES}

Alavi, M., \& Mansor, S. M. S. (2011). Categories of problems among international students in Universiti Teknologi Malaysia. Procedia - Social and Behavioral Science, 30, 1581-1587. doi:10.1016/j.sbspro.2011.10.307.
Anderson, J. R, Guan, Y., \& Koc, Y. (2016). The academic adjustment scale: Measuring the adjustment of permanent resident or sojourner students. International Journal of Intercultural Relations, 54, 68-76. doi:10.1016/j.ijintrel.2016.07.006

Aspelmeier, J., Love, M., McGill, L., Elliott, A., \& Pierce, T. (2012). Self-esteem, locus of control, college adjustment, and GPA among first- and continuing-generation students: A moderator model of generational status. Research in Higher Education, 53, 755-781. doi:10.1007/s11162-011-9252-1

Ayu, W. (3 Desember 2019). UI Raih Peringkat 59 Perguruan Tinggi di Asia. Artikel diunduh dari https://www.ui.ac.id/ui-raih-peringkat59-perguruan-tinggi-di-asia/

Bastien, G., Seifen-Adkins, T., \& Johnson, L. R. (2018). Searching for success: Predictors of academic adjustment of international students. Journal of International Students, 8, 1198-1219. doi:10.5281/zenodo. 1250421

Brislin, R. W. (1970). Back-translation for cross-cultural research. Journal of CrossCultural Psychology. 1, 185-216. doi:10.1177/135910457000100301

de Araujo, A. A. (2011). Adjustment issues of international students enrolled in American colleges and universities: A review of the literature. Higher Education Studies, 1, 2-8. doi:10.5539/hes.v1n1p2

Heppner, P. P., Kivlighan, D. M., Good, G. E., Roehlke, H. J., \& et al. (1994). Presenting problems of university counseling center clients: A snapshot and multivariate classification scheme. Journal of Counseling Psychology, 41(3), 315-324. doi:10.1037/0022-0167.41.3.315 
Hwang, B. J., Bennett, R., \& Beauchemin, J. (2014). International students' utilization of counseling services. College Student Journal, 48, 347-354

Israelashvili, M. (2012). Should adjustment disorder be conceptualized as transitional disorder? In pursuit of adjustment disorders definition. Journal of Mental Health, 21, 579-588. doi:10.3109/09638237.2012.670881

Kaaya, S. F., Fawzi, M. C. S., Mbwambo J. K, Lee B., Msamanga G. I., \& Fawzi W. (2002). Validity of the Hopkins Symptom Checklist-25 amongst HIV positive pregnant women in Tanzania. Acta Psychiatrica Scandinavica, 106, 9-19. doi:10.1034/j.1600-0447.2002.01205.x

Khawaja, N., \& Stallman, H. (2011). Understanding the coping strategies of international students: A qualitative approach. Australian Journal of Guidance and Counselling, 21, 203-224. doi:10.1375/ajgc.21.2.203

Mesidor, J. K., \& Sly, K. F. (2016). Factors that contribute to the adjustment of international students. Journal of International Students, 6, 262-282.

Mori, S. (2000). Addressing the mental health concerns of international students. Journal of Counseling \& Development, 78 , 137-145. doi:10.1002/j.1556$\underline{6676.2000 . t b 02571 . x}$

Pengantar Program Internasional Universitas Indonesia. (Maret, 2013). Diunduh dari www.ui.ac.id/international/page/penganta r

Peraturan Menteri nomor 25 tahun 2007. (Maret, 2013). Diunduh dari http://portal.mahkamahkonstitusi.go.id/e Law/mg58ufsc89hrsg/Mendiknas 2520 07.pdf
Puspitorini, Dwi. (2013, Juni 20). Ketua Program BIPA FIB UI. Wawancara pribadi.

Sagone, E., \& De Caroli, M. E. (2014). Locus of control and academic self-efficacy in university students: The effects of Selfconcepts. Procedia - Social and Behavioral Science, 114, $222-228$. doi:10.1016/j.sbspro.2013.12.689

Salmah, I. (2016). Culture shock dan strategi coping pada mahasiswa asing program darmasiswa (studi kasus pada mahasiswa asing program darmasiswa Samarinda). Psikoborneo, 4, 857-867.

Schwartz, S. J., Zamboanga, B. L., Luyckx, K., Meca, A., \& Ritchie, R. A. (2013). Identity in Emerging Adulthood: Reviewing the Field and Looking Forward. Emerging Adulthood, 1, 96-113. doi:10.1177/2167696813479781

Shaifa, D., \& Supriyadi, S. (2013). Hubungan dimensi kepribadian The Big Five Personality dengan penyesuaian diri mahasiswa asing di Universitas Udayana. Jurnal Psikologi Udayana, 1, 72-83. doi:10.24843/JPU.2013.v01.i01.p08

Sherry, M., Thomas, P., \& Chui, W-H. (2010). International students: A vulnerable student population. Higher Education, 60, 33-46. doi:10.1007/s10734-009-9284-z.

Shu, F., Ahmed, S. F., Pickett, M. L., Ayman, R., \& McAbee, S. T. (2020). Social support perceptions, network characteristics, and international student adjustment. International Journal of Intercultural Relations, 74, 136-148. doi:10.1016/j.ijintrel.2019.11.002

Smith, R. A., Khawaja, N. G (2011). A review of the acculturation experiences of international students. International Journal of Intercultural Relations, 35, 699-713. doi:10.1016/j.ijintrel.2011.08.004 
Stoeber, J., Childs, J. H., Hayward, J. A., \& Feast, A. R. (2011). Passion and motivation for studying: Predicting academic engagement and burnout in university students. Educational Psychology, 31, 513-528. doi: $10.1080 / 01443410.2011 .570251$

Turnip, S. S., \& Hauff, E. (2007). Household roles, poverty, and psychological distress in internally displaced persons affected by violent conflicts in Indonesia. Social Psychiatry and Psychiatric Epidemiology, 42, 997-1004. doi:10.1007/s00127-007$\underline{0255-3}$

Turnip, S. S., Klungsøyr, O., \& Hauff, E. (2010). The mental health of populations directly and indirectly exposed to violent conflict in Indonesia. Conflict and Health, 4, 14. doi:10.1186/1752-1505-4-14

Tirto, A., \& Turnip, S. (2019). The accuracy of Hopkins Symptom Checklist - 25 (HSCL-25) depression subscales (Indonesian version) on adolescents. HUMANITAS: Indonesian Psychological Journal, 16, 1-12. doi:10.26555/humanitas.v16i1.10143

Um, B. (2018). Ego-resiliency, parenting style, and peer attachment as predictors of south korean middle school students' school adjustment. International Journal of Social Science Studies, 6, 14-30. doi:10.11114/ijsss.v6i7

Universitas Indonesia. (2020). Registration guide for international applicants: Predeparture. Diunduh dari https://penerimaan.ui.ac.id/page/foreign.

University of Indonesia rankings: Asian University Rankings 2018. (30 April 2019). Diunduh dari https://www.topuniversities.com/universi ty-rankings/asian-universityrankings/2018.

Waghachavare, V. B., Dhumale, G. B., Kadam, Y. R., \& Gore, A. D. (2013). A study of stress among students of professional colleges from an urban area in India. Sultan Qaboos University medical journal, 13, 429-36. doi:10.12816/0003266

Wang, K. T., Heppner, P. P., Fu, C.-C., Zhao, R., Li, F., \& Chuang, C.-C. (2012). Profiles of acculturative adjustment patterns among Chinese international students. Journal of Counseling Psychology, 59, 424-436. doi:10.1037/a0028532

Wu, W., \& Hammond, M. (2011). Challenges of university adjustment in the UK: A study of East Asian Master's degree students. Journal of Further and Higher Education, $\quad 35, \quad 423-438$. doi:10.1080/0309877x.2011.569016

Wu, H. P., Garza, E., \& Guzman, N. (2015). International student's challenge and adjustment to college. Education Research International. doi:10.1155/2015/202753

Yusoff, M. S., Abdul Rahim, A. F., \& Yaacob, M. J. (2010). Prevalence and sources of stress among universiti sains malaysia medical students. The Malaysian Journal of Medical Sciences : MJMS, 17(1), 3037. doi: 10.5959/EIMJ.V5I4.190

Zhang, J. \& Goodson, P. (2011). Predictors of international students' psychosocial adjustment to life in the United States: A systematic review. International Journal of Intercultural Relations, 35, 139-162. doi:10.1016/j.ijintrel.2010.11.011 